\title{
The Developments on Audit Quality in Indonesia: The Qualitative Analysis on the Practitioners' Expectations
}

\author{
Irma Tyasari \\ Tunku Puteri Intan Safinaz School of Accountancy \\ Universiti Utara Malaysia \\ Sintok, Kedah, Malaysia \\ Universitas Kanjuruhan Malang \\ Irma.fe@unikama.ac.id or irmatyasari26@gmail.com
}

\begin{abstract}
Indonesia has a continuous concerned on its audit quality (AQ) since the impact of global changes on the country's accounting profession. The data was obtained from face-to-face interviews with practitioners which have given the notion on how far Indonesia has already gone to enhance its AQ. Review of documentary material which was obtained from on the official websites of parties and observation of routine activities of the participants also involved in this study. The discussion of the developments focused on the way to implement $A Q$ conducted by each participant. Institutional analysis was derived directly from data obtained. The findings explained regulators' roles have created significant efforts to the development on audit quality. In addition, it also shows the implementation of AQ conducted by practitioners in their audit firm. Therefore, those created the expectation of most of practitioners to obtain monetary and nonmonetary value-added impact significantly because of the regulatory efforts. This paper is a contribution to the literature on the subject of $A Q$ by providing the insights into how Indonesia as an emerging country responded to the global demands on AQ improvements and the expectation of the practitioners regarding to the changes.
\end{abstract}

Keywords-Audit Quality, Regulatory Changes, Efforts, Expectation, Practitioner

\section{INTRODUCTION}

The role of accounting profession is crucial as it provides assurance on a business's financial statements to the stakeholders. High quality audit which are based on these statements provides the necessary information to influence investment decisions, which in turn will benefit the business directly and economy in general [1] ; [2]; [3]. Some opined that the product of accountants has been considered as "the language of business" [4]. The issue involving Enron and its auditor in the early 2000's had forced the policy makers to revise and amend the auditing approaches which have significantly affected the accounting profession [5]. Thus, the Indonesian regulators have responded accordingly to meet the global as well as the local demands to address and improve its audit quality. Several efforts were conducted by the regulators such as adopting the international auditing and accounting standards, restructuring the main institutional drivers of audit quality such as the P2PK and the OJK, and enhancing a new law and regulation [6]. The biggest question to be answered, by a developing country like Indonesia in assessing each of its efforts to improve audit quality, is to determine the most crucial one [7]. This is important because the nation will emphasize on that particular efforts and conduct a suitable reformation effectively in order to achieve a high quality audit and financial reporting practices [7]. In Indonesia, experience in practical problems receives the most attention as it leads to the loss of confidence in the audit quality. According to the input gathered during interviews with regulators, most of them believe that the audit quality has not been implemented properly in any type of audit firms. Therefore, this situation is deemed as a challenge for them. The small and medium audit firms are assumed to face difficulty in adopting the changes due to insufficient resources. These firms implicate that the changes involved have created high compliance costs. On one part, they have to fulfill all the requirements given by the regulators and on the other part; they also need to develop their firms to comply with the standards with their limited resources. Another problem is related to the overlapping implementation, i.e. the quality inspection or review. Every government agencies such as the OJK, P2PK and the IAPI have their own inspection schedule set on the audit firms. However, the nature of the inspection of each agency is almost similar in term of the purpose, the standard used and the output. The practitioners must comply with the inspections of the respective agencies, and they are aware that this efforts conducted by the regulators will bring about the behavioral change in the accounting profession. However, while they are obliged to implement the regulation and adhere to the standards, and expected to receive a proper incentive and benefits by performing good practice and utilizing common quality policies, still they are penalized due to the inconsistency of implementing the requirements. The abovementioned problems are the motivation of this study and each country including Indonesia has its own unique institutions that are responsible to oversee that new regulation are being appropriately implemented by the practitioners 
There are numerous studies regarding institutional research on audit quality such as [8] who had analyzed the auditing regulatory regime in different nations due to the varying approach of the audit quality implementations. The researchers in their discussions included that the difference in culture, legal protection, economic development and the differing financial standards are the sources which will affect audit quality in different countries. Another research was regarding the strategic response in the local context during institutional change [9] and finally, a study regarding the comparison of regulatory changes in terms of corporate governance and internal control over the financial reporting [10]. In the case of Indonesia, empirical research on regulatory changes such as the regulators' efforts and audit quality received less attention since most prior studies focused audit quality with certain dimensions such as competency, independency [11], audit tenure [12], audit industry [13] and etc.

The purpose of this study is to provide qualitative analysis on the practitioners' expectations and influence their practice in audit firms regarding the regulators' efforts in order to enhance audit quality in Indonesia. Adopting institutional theory will be the method of analysis to address the data obtained. Therefore, this study contributes to the literature by providing further insight into the contextual condition that prompts the regulatory efforts, which will enhance the understanding on the impact of these efforts and the improvements on audit quality in Indonesia. This study also provides contribution to the institutional theory by showing how institutions in Indonesia regulate auditing in its own legal structure. In addition, this paper will also provide the insights of the practitioners' expectations and influence of their practices on the regulatory efforts through in-depth interviews with the global and local practitioners. This approach will clearly illustrate a comprehensive phenomenon rather than relying on the secondary data. Thus, this paper is organized as follows: The first section is the introduction and the second section explains the context of institutional theory. The third section discusses the literature review, the fourth section justifies the research questions and methodology and lastly, the fifth section presents the result including the discussion on the implication of the research.

\section{INSTITUTIONAL THEORY AND INDONESIAN REGULATORY CHANGES}

Institutional theory is used to develop a theoretical framework that will help to understand the process of the regulatory changes that influence audit quality in Indonesia. According to [14], the process by which organizations tend to adopt the same structures and practice is known as isomorphism or described as a homogenization of organizations. The definition of isomorphism itself is a process that causes one unit in a population to resemble other units in the same population that share the same set of environmental condition [14]. Thus, in order to obtain legitimacy, access facility to resources and risk avoidance, conforming to institutional rules and norms should be confirmed [14]; [15]. There are three mechanisms of institutional isomorphic change: a) coercive isomorphism; b) mimetic isomorphism; and c) normative isomorphism. For the purpose of this study, the institution refers to the regulators. It shows how the regulators emerged and developed, and conclusively affect policy outcomes for the practitioners. In discussing the institutionalization impact of the regulatory changes on AQ will also create an impact for the practitioners. The isomorphism used in this study is coercive and normative. The term coercive isomorphism may either be formal and informal pressure or influence from other organizations due to political, cultural or legal environments [14]. Coercive pressure that originates from the regulators on audit firms' environment has created definite rules, that the practitioners must comply, and the regulators have the power to reward or punish them. In short, the regulators use their power to force practitioners to engage in certain actions or activities. While the normative isomorphism, it occurs when institutional change interpreted under professionalization [14]; [15]. This is very important sources of isomorphism to keep aspects of professionalization. As a practitioner, formal education and skill of specialization are required. Based on the mechanisms of institutional isomorphic change above, this study has identify the type of the institutional theory implemented in Indonesia's audit quality due to the impact of the regulatory changes especially to the practitioners.

\section{LITERATURE REVIEW}

\section{A. Audit Quality, Regulators, and Practitioners}

There is no end in discussing AQ. Previous researchers have studied AQ with various dimensions or factors that influence it either with consistent or different results [7];[16]. They have identified and categorized AQ in various views, whether direct or indirect measure of AQ; studies that are based on sources of differentiation; studies that rely on input, process, output; behavioral perspectives; market based perspectives; organizational aspects and others [7]; [16]. Most of the studies relate AQ to regulators and practitioners and is relevant as to what the International Auditing and Assurance Standard Board (IAASB) refers as

among the AQ elements in their Framework of AQ-Key Elements. According to IAASB AQ is best achieved in an environment where there is support from, and appropriate interactions among the elements and participants in the financial reporting supply chain [17]. The past decade has seen a lot of changes in the regulations of the auditing profession, including in Indonesia. The changes serve as a guide for practitioners to perform the best approach in regards to accomplish AQ. Practitioners are required to comply with the relevant auditing standards, ethics and regulatory requirements within their audit firms. As a result the practitioners sometimes faced challenges due to the regulatory changes [18]; [19]; [20].

\section{B. The Regulatory Changes}

Accounting practitioners and their services cannot be separated from the related regulations since the profession directly affects public interest [21]; [22]; [23]. New accounting regulation is inevitable as the necessity to change has taken place since the advent of the profession. The 
regulation tends to be dynamic and represents the change that transpires within the profession. Regulations are also inseparable from government's intervention as well as the professional bodies, because regulations exist to protect the interests of the many, and serve as a response to the current events. The most popular regulatory changes were The Sarbanes-Oxley Act (SOX) of 2002 in the US [24] and the Corporate Law Economic Reform Program Act (CLERP) 9 of 2004 in Australia [25]. Since then there were many researches that studied the impact of SOX and relate it to in a AQ whether in a direct or indirect relationship, such as studies were conducted by [25]; [20]; [26]; [19]; [26]; [27] and [18]. Based on the studies mentioned, it can be summarized that there are two different points of views, on whether regulatory changes influence the audit quality directly and significantly or otherwise, by using various dimensions. The methodological approaches used by prior literature also differs significantly with regards to population, sample, scope, adopted approach, and data analysis method which had led to differences in conclusions. Most of the discussions revolve around the impact of regulatory changes on audit quality. Additionally, most of these studies were conducted in developed countries.

Another study which was conducted in China had examined two rules issued by China's State-owned Assets Supervision and Administration Commission of the State Council (SASAC) whether the regulations that limit management influence over auditors improve audit quality [28]. It was found that limiting management influence over auditors does improve audit quality, in this case especially for state-owned enterprises that are ultimately controlled by the central government (CSOEs). Similar study regarding regulatory changes and audit quality in emerging country was also conducted in China [29]. They examined the legal and regulatory changes that affect the relationship between audit quality and the clients economic importance from 1995 to 2000 and 2001 to 2004. The results show significant differences and contradictory between the two periods of analysis. It can be summarized that the number of studies which focused on regulatory changes and audit quality in emerging countries is very limited. Most of the studies were conducted in China, and the main different among these studies was a diverse legal environment, in this case related to auditing profession. For example the differences were in terms of statutory audit requirements, standards and standards setting, the competence requirement of auditors, and reporting obligations. The difference may create differential of audit quality's atmosphere [30]. In the case of Indonesia, the empirical research on regulatory changes such as the regulators' effort and audit quality is low as well. Most of them were concerned with audit quality and similar dimensions such as: Auditor's Industry Specialization, Auditor's Procedures [13], audit's tenure [12], and auditors' competency, experience and independency [11]; [31]; [32]. In addition, most of the existing studies had utilized quantitative or experimental case approach to obtain data Hence, this study is designed to look into the views and expectations of the parties involved in auditing by conducting in-depth qualitative study, and to show the states' role, efforts and developments to improve audit quality, in the case of how far Indonesia has gone in order to enhance its AQ.

\section{METHOLOGICAL APPROACH}

The aim of this paper is to investigate how the practitioners' expectations and practices are influenced by the regulators' efforts in order to enhance audit quality in Indonesia. Hence, as to fulfill the aim of the study, the research questions are addressed as follows:1) How do the regulators efforts enhance audit quality?; 2) how do the regulatory efforts influence practice in audit firms?; and 3) what are the practitioners' expectation towards the efforts?. In order to answer these questions, institutional analysis is used and it concerns institutional change. According to [33], in order to identify the pattern of institutional change, a starting point need to be determined at which the change occurs as a result of specifying dimension of the institutions. Therefore, the identifying pattern started from the year 2007 to 2016 and the regulators used coercive theoretical perspective dimensions. As mention above, coercive pressure comes from the regulators to the audit firms' environment which creates direct rules, and the practitioners must comply with or else they will be penalized. In short, the regulators used their power to force practitioners to engage in certain actions or activities.

This study employs qualitative approach [34]. Data was collected from face-to-face interviews, personal observations and secondary data sources. The institutional analyses were used to utilize it, to make sense of the data. The participants' selection for this study was practically and theoretically accomplished based on their experience. The participants are divided into two main groups which are; the regulators and professional bodies in one group; and the global practitioners and local practitioners in another group. For the purpose of this study, the definition of a global practitioner is a practitioner who works in an audit firm which has international professional service network. Each entered into an agreement with member firms in the network to share a common name, brand and quality standards [35]. The total of participants selected were twenty nine (29) participants of which eight (8) participants were regulators and the remaining twenty-one (21) wee practitioners. The interviews duration varies from 38 to 100 minutes for every participant, and were conducted independently. The interviewer used key point's questions as the instrument. Additionally, in order to support the result of the interviews and strengthened the reliability of the conclusions, archival material such as annual reports and other confidential documents from the officers were reviewed as well. Based on the data analyzed, Fig 1 summarizes the findings and also shows the difference as well as compares the present result with the previous studies. 


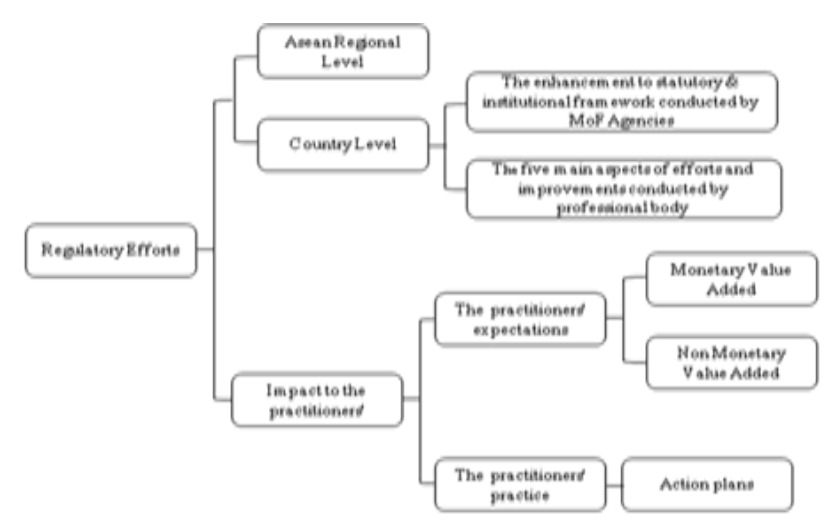

Fig 1 . The hierarchy code

\section{FINDINGS AND DISCUSSION}

As mentioned earlier, the purpose of this study is to investigate how the practitioner's expectations and practices are influenced by the regulators' efforts in order to enhance audit quality in Indonesia. Utilizing the institutional analysis, it shows that the efforts of the regulators signaled significant changes in accountancy environment i.e. the enhancement to statutory and institutional framework by the MOF agencies. This section will be divided into four subsections: 1) regulatory efforts; 2) practitioners' practice; and 3) practitioners' expectation.

\section{A. The Regulatory Efforts}

Regulators play significant role in showing Indonesia's commitment to improve and enhance AQ. The efforts are not only conducted at the country level, but also at the ASEAN regional level. One of the collaborative activities with other ASEAN countries was the ASEAN Audit Regulators Group (AARG) meeting and inspection workshop conducted in Bali in January 2016. The workshop focused on information and knowledge sharing activities on guidance and supervision of Independent Audit Regulators and the Public Accounting Firm. In addition, it was a platform of collaboration and dialogue between ASEAN audit regulators, aiming at achieving consistent cooperation and increasing audit quality provided by Independent Audit Regulators and accounting firms [6]. The activity not only portrays the roles and efforts performed by the Indonesia, but also shows part of the collaborative efforts among ASEAN countries.

At the country level, the regulators focus on the enhancement of the statutory and institutional framework. It means that how the basis of effective regulations are put in place. The purpose is to monitor and supervise the practitioners, and to improve the accounting and the auditing mechanism. The significant output for the efforts is: the issuance of Act No. 5/2011,; The Government Rule (PP) No. 20/2015,; the MOF Decree No. 263/KMK01/2014,; the MOF Decree No 25/KMK.01/2014 and the Government Rule (PP) No. 84/2012. These regulations are regarding the accountancy profession and expected to impact the AQ. Instead of having enhancement to statutory and institutional framework, the regulators have restructured the MOF agencies such as the P2PK and the OJK. As mentioned by RG01,; RG02,; and
RG03, the purpose of these changes is to extend the responsibilities and improve the capacity building of the respective agencies in order to meet the current demands. In addition, the regulators have decided to adopt international standards and given the task to the standard setters (IAPI and IAI) to move toward the convergence to these standards. As stated by PB03, the current task is still being in progress which is the reevaluation of the 2006 version of the ethics code to update it in line with the Handbook of The Code of Ethics for Professional Accountants 2016 Edition, issued by the IESBA. Besides preparing the standards, the professional bodies have identified five main aspects of improvements as well as preparing the draft of Audit Quality Indicators (AQIs), as proclaimed by $\mathrm{PB} 02$ and $\mathrm{PB} 03$ :

“(.) we have five major aspects of efforts in order to improve audit quality, namely: 1) improving individual quality and the competence of public accountant profession; 2) providing and improving the auditing standards (SPAP) and code of conduct referring to international standards; 3) encouraging to improve the capacity and quality of public accountant and audit firm's services; 4) improving and strengthening the practice of good governance in within an organization; and 5) improving the involvement and legal advocacy regarding the relevant regulations for this profession (..).The most current progress that the professional bodies consistently support and significantly involve in enhancing $A Q$ is the socialization of the IAPI's Statutes and Bylaws' Revision draft, in order to establish Public Interest Oversight, and the issuing of the exposure draft of Audit Quality Indicators (AQIs) from October to November 2016 (....).",

These efforts are the management strategic action programs conducted by the professional bodies that will support the enhancement of audit quality. Based on the analysis, the finding of this section presents an institutional analysis of the emergence of the commitment towards regulatory efforts. Because of external pressures, the regulators efforts were conducted together from the ASEAN regional to the country level, to show Indonesia's commitment to improve and enhance AQ. The professional bodies also provide strategic efforts that will support it as well. These efforts could be a result of normative as well as coercive pressure which will keep professionalism in providing assurance service.

\section{B. The Practitioners' Actions (Practice)}

Most of the participants responded to the question about how the regulatory efforts influence their practice in audit firms. They claimed that the direct influence for them is the shift of their thinking, or which put them into applying the risk based thinking or "critical thinking" to some [36]. Hence, $90 \%$ of the practitioners said that they need to prepare "a huge project or action plan" since they have lots of things to do; and one of the actions is to revise their internal audit manual to meet with the new auditing standards. Forty eight percent of the global practitioners asserted that their "manual book" have high degree of compliance with the ISAs, while the local practitioners claimed compliance with some significant differences; and due to this they require more time to refine it. 
AP01, AP05, AP6 and AP07 stated about their affiliation's facilities:

“(..) we have prepared well for the new audit standards, and we even have done internal training programs for our auditors. Our global affiliates shared and provided the updated quality audit policies, practice and also methodologies.(..) we considered that we are ready for the changes."

They said that their actions are not only focused on the auditing standards, but also fulfilling practice requirements, new enforcements approach, as mentioned on the new regulation for practitioners, and updating accounting standards as well, which until the last of 2016, the standard setter are still launching and updating these standards. AP03, AP04, and AP09 considered that the practitioners have no choice except to comply, even though the impact is hard and costly, especially for the small and medium audit firms, which are owned by the local practitioners. Most of the local practitioners have limited resources, and now they also have to be more careful in accepting assurance engagements due to the pressure of high quality output at lower fee. This section they claimed that there is a significant different between the global and local practitioners in reacting and responding to the changes. All agreed that the two parties may struggle to meet with the regulations as well as the new international standards based on the resources and capacity they owned.

\section{The Practitioners' Expectations}

The third question of this study explores whether different size of accounting firms reacted differently to the regulatory efforts in order to enhance AQ in Indonesia. Although they reacted differently in response to the regulators' efforts, but they shared the same opinion regarding their expectations. Most of them agreed that the regulatory efforts may offer the opportunity to engage with more clients, determine a minimum assurance fee and provide free or affordable professional training programs for the members, especially for the auditors not for the partners. They also expected that the new act and regulations will make auditing as a more desirable profession for the young accountants as the audit firms have higher possibility to earn higher turnover. These also will protect the profession legally and the finally, the practitioners expect that the regulatory efforts may help to decrease the gap among the practitioners i.e. the gap of having the resources and market share (AP01; AP02; AP05; AP08; AP10).

“(..) this regulation may improve the profession in term of financial benefit, or we can say the clients may want to pay for the quality of money because they assumed that they will get better service by paying more fees to the practitioner."

Hence, based on the explanations above, it finds that all of the participants also share a similar view about the expected benefit they can get by complying with the regulatory changes. This expectation can be divided into two categories, the first is monetary value added which is related to the quality of money. This refers to the value regarding the audit fee, or called as financial benefit, and the practitioners may possibly get more clients which will eventually increase their assurance revenue. The second is the non-monetary value added which include the awareness of being more professional as an accountant (improving the competency; good reputation; better attitude and mental; competitive). Besides that the practitioners also expect that the regulatory efforts will protect the profession legally and decrease the gap among the global and local practitioners. In addition, the regulatory changes may improve the awareness of related the parties such as the clients, the stakeholders to be more confident with a business that employs qualified auditors. The practitioners also expect regulators to be consistent in promoting and realizing the enhancement of AQ in Indonesia, since they are the authority to carry out such task.

\section{CONCLUSION AND IMPLICATIONS}

This study has investigated the practitioners' expectation qualitatively regarding the regulatory efforts conducted in Indonesia. Based on the analysis, it can be concluded that the regulators' efforts have created a significant impact on the practitioners in order to improve the audit quality. However, the practitioners react to the regulatory efforts differently. The global practitioners are always prepare to face the changes as they have strong connection with the professional international network services, while their local counterpart find it a challenge as they lack the necessary resources. However, the two group shares the same view that they may have to struggle to meet the regulations as well as the new international standards. In addition to that, all of them perceive similar views regarding the benefits that they may receive by having the regulatory changes, in the form of monetary and nonmonetary value added. Finally the practitioners expect that the regulators will keep on promoting and enhancing the practitioner's work quality in order to raise the confidence of the clients and other stakeholders. However, the finding of this study needs to be understood as the regulators efforts are still taking place since the year 2007. Therefore, the implementation of AQ may show continues improvement and still requires the participations of all parties related to the accounting professions.

\section{REFERENCES}

[1] J. DeFond, M., \& Zhang, "A review of archival auditing research," Journal of Accounting and Economics," J. Account. Econ., vol. 58, no. 2, pp. 275-326, 2014.

[2] D. Francis, J. R., \& Wang, "The joint effect of investor protection and Big 4 audits on earnings quality around the world," Contemp. Account. Res., vol. 25, no. 1, pp. 157-191, 2008.

[3] J. S. Datar, S. M., Feltham, G. A., \& Hughes, "The role of audits and audit quality in valuing new issues," J. Account. Econ., vol. 14, no. 1, pp. 3-49, 1991.

[4] J. Z. Rezaee, Z., Smith, L. M., \& Szendi, "Convergence in accounting standards: Insights from academicians and practitioners," Adv. Account., vol. 26, no. 1, pp. 142-154, 2010.

[5] S. Asthana, S., Balsam, S., \& Kim, "The effect of Enron, Andersen, and Sarbanes-Oxley on the US market for audit services," Account. Res. J., vol. 22, no. 1, pp. 4-26, 2009.

[6] Kemenkeu, "Pusat Pembinaan Profesi Keuangan (PPPK)," 2015.

[7] J. R. (2011) Francis, "A framework for understanding and researching audit quality", Auditing: A journal of practice \& theory," Audit. A J. Pract. theory, vol. 30, no. 2, pp. 125-152, 2011. 
[8] D. Kleinman, G., Lin, B. B., \& Palmon, “Audit quality: A cross-national comparison of audit regulatory regimes," J. Accounting, Audit. Financ., vol. 29, no. 1, pp. 61-87, 2014.

[9] B. Canning, M., \& O’Dwyer, "The dynamics of a regulatory space realignment: Strategic responses in a local context," Accounting, Organ. Soc., vol. 38, no. 3, pp. 169-194, 2013.

[10] J. C. Hoitash, U., Hoitash, R., \& Bedard, "Corporate governance and internal control over financial reporting: A comparison of regulatory regimes," Account. Rev., vol. 84, no. 3, pp. 839-867, 2009.

[11] Octavia and Widodo, "The effect of competence and independence of auditors on audit quality," Res. J. Financ. Account., vol. 6, no. 3, pp. 189-194, 2015.

[12] R. Febrianto and S. Sugiri, “A Test of Indonesian Ministry of Finance's Decree Effectiveness," 2016.

[13] I. Sarwoko and S. Agoes, “An Empirical Analysis of Auditor's Industry Specialization, Auditor's Independence and Audit Procedures on Audit Quality: Evidence from Indonesia," Procedia-Social Behav. Sci., vol. 164, pp. 271-281, 2014.

[14] P. DiMaggio and W. W. Powell, "The iron cage revisited: Collective rationality and institutional isomorphism in organizational fields," $\mathrm{Am}$. Sociol. Rev., vol. 48, no. 2, pp. 147-16, 1983.

[15] W. R. Scott, "Approaching adulthood: the maturing of institutional theory," Theory Soc., vol. 37, no. 5, p. 427, 2008.

[16] A. Aghaei Chadegani, "Review of studies on audit quality," 2011.

[17] IFAC, "International Auditing and Assurance Standard Board," 2AD.

[18] A. Hecimovic and N. Martinov-Bennie, "The differential impact of the force of law Australian Auditing Standards," Aust. Account. Rev., vol. 21, no. 2, pp. 183-192, 2011.

[19] R. Fearnley, S., Brandt and T. Hines, "The impact of changing regulation on the behavior and perception of UK Directors and auditor," 2014.

[20] M. L. DeFond and C. S. Lennox, "The effect of SOX on small auditor exits and audit quality," J. Account. Econ., vol. 52, no. 1, pp. 21-40, 2011.

[21] T. Lee, "The professionalization of accountancy: a history of protecting the public interest in a self-interested way," Accounting, Audit. Account. $J$. , vol. 8, no. 4, pp. 48-69, 1995.

[22] X. Deren, "The Theoretical Analysis: The Regulation Model of CPA Industry," Account. Res., vol. 2, no. 1, 2002.

[23] C. Hayes, "The Ramsay report and the regulation of auditor independence in Australia," AAR, vol. 12, no. 2, 2002.

[24] R. Romano, "The Sarbanes-Oxley Act and the making of quack corporate governance," 2004.

[25] S. Hossain, "Effect of Regulatory Changes on Auditor Independence and Audit Quality," Int. J. Audit., vol. 17, no. 2, p. 18, 2013.

[26] C. Holm and M. Zaman, "Regulating audit quality: Restoring trust and legitimacy," Account. Forum, vol. 36, no. 1, pp. 51-61, 2012.

[27] J. L. Smith, "Investors' perceptions of audit quality: Effects of regulatory change," Audit. A J. Pract. Theory, vol. 31, no. 1, pp. 51-61, 2012.

[28] K. Chi, W., Lisic, L. L., Long, X., \& Wang, "Do regulations limiting management influence over auditors improve audit quality? Evidence from China," J. Account. Public Policy, vol. 32, no. 2, pp. 176-187, 2013.

[29] D. Chen, S., Sun, S. Y., \& Wu, "Client importance, institutional improvements, and audit quality in China: An office and individual auditor level analysis," Account. Rev., vol. 85, no. 1, pp. 127-158, 2010.

[30] M. Favere-Marchesi, "Audit quality in ASEAN," Int. J. Account., vol. 35, no. 1, pp. 121-149, 2000.

[31] W. Idawati and A. Gunawan, "Effect of Competence, Independence, and Professional Skepticism Against Ability to Detect Fraud Action in Audit Assignment (Survey on Public Accounting Firm," in IICPA, 2015.

[32] R. Halim, A., Sutrisno, T. and M. Achsin, "Effect of Competence and Auditor Independence on Audit Quality with Audit Time Budget and Professional Commitment as a Moderation Variable," Int. J. Bus. \&Management Invent., vol. 3, no. 6, pp. 64-74, 2014.
[33] J. L. Campbell, Institutional change and globalization. New Jersey: Princeton University Press, 2004.

[34] N. K. Denzin, Introduction: The discipline and practice of qualitative research, NK Denzin, YS Lincoln (Eds.), Handbook of qualitative research (3rd ed.). New York: Sage Publications, 2005.

[35] H. Lenz and M. L. James, "International audit firms as strategic networks-The evolution of global professional service firms," Econ. Manag. networks, pp. 367-392, 2002.

[36] T. M. Tuanakotta, Audit Berbasis ISA (International Standards on Auditing). Jakarta: Salemba Empat, 2013. 